\title{
Dukungan Psikososial terhadap Anak Penderita Retardasi Mental di SLB Widya Bhakti Semarang
}

\author{
${ }^{1}$ Ahmadi Nur Huda*, ${ }^{1}$ Elly Noerhidajati, ${ }^{1}$ Rizki Woro Hastuti, ${ }^{2}$ Siti Maesaroh \\ ${ }^{1}$ Program Pendidikan Profesi Dokter, Fakultas Kedokteran Universitas Islam Sultan Agung, Indonesia \\ ${ }^{2}$ Sekolah Tinggi Agama Islam Walisembilan, Semarang, Indonesia \\ *Corresponding Author \\ Jalan Raya Kaligawe Km.04 PO Box 1054 Telp.(024)6583584 Fax.(024)6594366 Semarang 50112 \\ E-mail: ahmadinh21@gmail.com

$\begin{array}{llll}\text { Received: } & \text { Revised: } & \text { Accepted: } & \text { Published: } \\ \text { 24 April 2020 } & \text { 17 May 2020 } & \text { 26 May 2020 } & \text { 25 December 2020 }\end{array}$

\begin{abstract}
Abstrak
Mitra merupakan siswa-siswi SLB Widya Bhakti Semarang yang mempunyai keterbatasan intelektual dan adaptasi. Untuk membantu mengurangi keterbatasan mitra diberikan dukungan psikososial. Kegiatan ini bertujuan menganalisis data demografi dan respons mitra terhadap dukungan psikososial. Metode pelaksanaan kegiatan ini menggunakan metode kemitraan dengan sifat pendekatan kualitatif dan kuantitatif sederhana, dilakukan pemberian dukungan psikososial berupa edukasi remidiasi kognitif, permainan sederhana, nyayian hiburan dan lagu perjuangan sebagai penyemangat. Hasilnya didapatkan mitra sebanyak 42 orang $(100 \%)$ data demografi berdasarkan jenis kelamin terbanyak laki-laki 27 anak $(64,3 \%)$, umur terbanyak 11-13 tahun 23 anak $(54,8 \%)$ agama mitra terbanyak Islam 39 anak $(92,8 \%)$, alamat terbanyak Semarang 36 anak $(85,6 \%)$, kelas mitra terbanyak $1-2$ ada 15 anak $(35,7 \%)$, pekerjaan orang tua terbanyak adalah swasta 31 anak $(73,8 \%)$. Setelah dilakukan program kemitraan masyarakat dengan pendekatan psikososial terdapat respons mitra yang bervariasi. Terbanyak mitra menyatakan: menyenangkan 42 anak $(100 \%)$, bermanfaat 42 anak (100\%), diperlukaan 37anak $(88,1 \%)$, kegiatan ini baik 42 anak (100\%), menyukai 38 anak $(90,5 \%)$.
\end{abstract}

Kata Kunci: Dukungan psikososial; anak retardasi mental.

\begin{abstract}
Our partners in this activity were SLB Widya Bhakti Semarang students who have intellectual and adaptation limitations. To help reduce the limitations of partners, psychosocial support was provided. This activity aimed to analyze demographic data and partners' responses to psychosocial support. The method of implementing this activity used a partnership method with a simple qualitative and quantitative approach, providing psychosocial support in the form of cognitive remediation education, simple games, entertainment songs and struggle songs as encouragement. The results obtained partners as many as 42 people (100\%), the most demographic data based on gender were 27 boys (64.3\%), the most age 11-13 years 23 children (54.8\%) the most partner religion was Islam 39 children (92.8\%), most address Semarang 36 children (85.6\%), most partner class 1-2 there were 15 children (35.7\%), most parents work was private 31 children (73.8\%). After the community partnership program was carried out with a psychosocial approach, there were various responses from partners. Most partners stated: it was fun for 42 children (100\%), useful for 42 children (100\%), needed for 37 children (88.1\%), this activity was good for 42 children (100\%), liked 38 children (90.5\%).
\end{abstract}

Keywords: Psychosocial support; a mentally retarded child. 


\section{PENDAHULUAN}

Mitra merupakan para siswa-siswi penderita retardasi mental yang mempunyai permasalahan keterbatasan fungsi adaptif dan intelektual yang sedang sekolah di SLB Widya Bhakti jalan Supriyadi nomor 12 Semarang. SLB Widya Bhakti Semarang merupakan SLB-C yang memilki akreditasi B dengan ijin operasional nomor: 425.1/0004164, tanggal 3 Juni tahun 2002. SLB Widya Bhakti Semarang telah di dirikan sejak tahun 1981 di atas lahan seluas 1548 meter persegi dengan luas bangunan 546 meter persegi yang memiliki jarak $2 \mathrm{~km}$. dari pusat kota Semarang dan $6 \mathrm{~km}$ dari arah timur kecamatan Mranggen kabupaten Demak. Kemudian SLB Widya Bhakti Semarang pernah mengalami renovasi bangunan pada tahun 2009. Status sekolah dan yayasan SLB Widya Bhakti Semarang adalah sekolah swasta yang dimiliki oleh Yayasan Widya Bhakti Semarang. Jadwal kegiatan belajar dan bermain (KBM) siswa dimulai pukul 07.00 - 13,00 dengan kegiatan ekstrakurikuler pramuka dan seni suara. Saat ini SLB - C Widya Bhakti Semarang telah memiliki banyak prestasi yang telah diraih diantaranya adalah pernah mendapatkan juara I lari 100 M. putra pada tahun 2012 dan juga pernah mendapatkan juara harapan II lari $80 \mathrm{M}$ putri pada tahun 2012.

Retardasi mental adalah suatu keadaan perkembangan mental yang terhenti atau tidak berkembang secara lengkap, yang terutama ditandai oleh adanya kekurang mampuan atau hendaya dalam ketrampilan motorik kasar dan motorik halus selama masa perkembangan, sehingga akan berpengaruh pada semua tingkat inteligensia atau kecerdasan penderita yaitu kemampuan fungsi kognitif, kemampuan berbahasa, ketrampilan motorik, dan ketrampilam perilaku sosial di masyarakat (PPDGJ-III), retardasi mental dapat terjadi dengan atau tanpa gangguan jiwa atau penyakit fisik lainnya. Namun demikian, penyandang retardasi mental bisa mengalamisemua gangguan jiwa yang ada, dan prevalensi dari gangguan jiwa lainnya sekurangkurangnya tiga sampai empat kali lipat pada populasi ini dari pada populai umum. Selain itu, penyandang retardasi mentalmempunyai risiko lebih besar untuk dieksploitasi dan diperlakukan salah secara fisik atau seksual (pshysical/sexual abuse). Pada retardasi mental sering bahkan selalu ada hendaya perilaku maladaptif, tetapi dalam lingkungan sosial terlindung dimana sarana pendukung cekup tersedia, hendaya ini mungkin bisa tidak tampak sama sekali pada penyandang retardasi mental ringan.

Dalam penulisan kode diagnosis retardasi mental karakter keempat dapat digunakan untuk menentukan ada tidak luasnya hendaya perilaku, bila hal ini bukan disebabkan oleh suatu gangguan lain yang menyertainya, seperti: tidak ada, atau terdapat hendaya perilaku minimal, atau terdapat hendaya perilaku yang bermakna dan memerlukan prhatian atau terapi, atau terdapat tidak hendaya perilaku lainnya, atau tanpa penyebutan ada tidaknya dari hendaya perilaku. Retarsi mental merupakan gangguan jiwa yang sering terjadi pada anak dan remaja dengan mempunyai permasalahan dan keterbatasan dalam fungsi kognitif dan adaptasi, sebagai gambaran klinis dapat terjadi sendiri maupun sebagai bagian dari gangguan mental atau gangguan kejiwaan yang lainnya, termasuk adanya hiperaktivitas, progresivitas, toleransi yang rendah terhadap permasalahan kehidupan dan sering terjadi frustasi, ketidak stabilan emosi, perilaku motorik terganggu, stereotipik, dan terkadang bisa mencederai diri sendiri. Terdapat defisit atau hendaya yang terjadi bersamaan di dalam fungsi adaptasi saat ini, dalam sedikitnya dua dari berikut ini: gangguan komunikasi, gangguan kehidupan dirumah dan lingkungan lain, perawatan diri kurang optimal, ketrampilan sosial dan personal kurang maksimal, gangguan penggunaan sumber komunitas, pengarahan diri, ketrampilan akademik fungsional, bekerja, bersanati, gangguan kesehatan secara umum, gangguan keamanan dan ketentraman.

\section{2 || Indonesian Journal of Community Services}


Insiden retardasi mental ringan dalam populasi umunya dimasyarakat terkadang tidak dikenali hingga masa anak mencapai umur pertengahan. Insiden tertinggi didapatkan pada anak usia sekolah, dengan usia puncak antara rentang usia 10-14 tahun, dalam populasi di masyarakat lebih sering pada anak laki-laki sekitar 1,5 kali dibandingkan dari pada anak perempuan. Pada sebagaian besar kasus anak dengan retardasi mental, adanya hendaya atau ketidak mampuan/kemunduran intelektual yang mendasari tidak akan membaik, tetapi pada tingkat adaptasi anak yang mengalami retardasi mental dapat secara positif mengalami perbaikan bermakna dapat dipengaruhi oleh lingkungan yang mendukung dan berkualitas baik. Anak dengan retardsai mental ringan dan sedang masih memiliki fleksibilitas tinggi dalam beradaptasi terhadap lingkungannya dan terhadap berbagai intervensi psikososial yang diberikan dan terhadap keadaan lingkungan sekitar yang ada.

Program dukungan psikososial merupakan serangkaian kegiatan yang terkoordinasi atas upaya medis, psikososial, edukasional dan vokasional untuk melatih seseorang yang memiliki hambatan dalam fungsi peran berupa fungsi kehidupan sehari-aharinya agar anak dengan retardasi mental dapat berfungsi secara seoptimal mungkin. Bagi penderita anak-anak retardasi mental bahwa pemberian obat saja tidak cukup, perlu adanya upaya komprehensif berupa dukunga psikososial dalam mengendalikan fungsi mental, sosial dan perilakunya seoptimal mungkin agar para penderita mampu melakukan aktivitas kehidupan sehari-hari serta upaya proses integrasi sosial, peran kehidupan sosial dan peningkatan kualitas hidup secara menadiri.

Penting juga dilakukan pemberian terapi secara komprehensif meliputi terapi somatik seperti obat-obatan atau terapi psikososial untuk memperpendek perjalanan penyakit mitra dan untuk meminimalkan gejala sisa atau hendaya yang ada dialami selanjutnya. Karena anak dengan retardasi mental sering memiliki kesulitan emosi dan kesulitan perilaku yang memerlukan bantuan psikososial dan terapi psikiatri. Kemampuan fungsi sosial dan kognitif yang terbatas pada anak retardasi mental memerlukan modalitas dukungan psikososial dan terapi psikiatri yang dimodifikasi. Pemberian program kemitraan masyarakat berupa pemberian dukungan psikososial secara komprehensif dengan memberika pelatihan ketrampilan adaptif, pelatihan ketrampilan sosial, dan pelatihan vokasional kejuruan akan sangat bermanfaat. Pemberian dukungan psikososial khusus difokuskan pada komunikasi mitra dan upaya untuk memperbaiki kualitas hidup mitra. Dukungan psikososial kelompok sering menjadi format tyang berhasil asalkan anak dengan retardasi mental dapat belajar dan mau mempraktikkan dalam situasi kehidupan nyata dan juga mendapatkan umpan balik yang positif dan mendukung.

\section{Tujuan Pengabdian}

Tujuan dari pengabdian Program Kemitraan Masyarakat (PKM) ini adalah: untuk mengetahui data demografi mitra, menganalisis respon dan tanggapan mitra terhadap kegiatan Program Kemitraan Masyarakat pemberian dukungan psikososial, membantu meningkatkan ketentraman atau kesehatan mitra dalam kehidupannya sehari-hari di sekolah dan di lingkungan masyarakat.

\section{METODE}

Kegiatan Program Kemitraan Masyarakat (PKM) dukungan psikososial ini menggunakan metode pendekatan kemitraan bersifat kaulitatif dan kuantitatif sederhana, dimana subyek atau mitra kegiatan program kemitraan masyarakat pemberian dukungan psikososial ini adalah para siswa-siswi penderita retardasi mental yang sedang sekolah di sekolah luar biasa (SLB) Widya Bhakti beralamat di jalan Supriyadi nomor 12 Semarang, dimana mereka adalah para anak-anak penderita retardasi mental yang mempunyai kebutuhan khusus, dengan tingkat kecerdasannya kurang dari kecerdasan normal dibandingan rata-rata anak pada umumnya, perhatian dan 
konsentrasinya juga kurang, interaksi dan sosialisasi dalam kehidupan bermasyarakat juga sering kurang optimal, demikian juga kurang mendapatkan dukungan psikososial dari masyarakat dan lingkungan hidupnya, bahkan kadang-kadang cenderung sering dikucilkan, diejek, diremehkan, kurang mendapatkan dukungan dan perhatian, bahkan cenderung dimarginalisasikan.

Untuk mengetahui tingkat berat ringannya gangguan retardasi mental pada mitra dapat dilihat dari data tes IQ yang telah ada di sekolah SLB Widya Bhakti Semarang, dimana bila IQ kurang dari nilai 20 termasuk retardasi mental sangat berat,atau termasuk kategori idiot, atau subnormalitas mental sangat berat, atau oligofrenia sangat berat,bila IQ berada dalam rentang nilai 20 sampai 34 termasuk menderita gangguan retardasi mental berat, atau termasuk subnormalitas`mental berat atau oligofrenia berat, bila IQ berada dalam rentang nilai 35 sampai 49 termasuk retardasi mental sedang, termasuk imbesil atau subnormalitas mental sedang atau oligofrenia sedang, dan bila IQ dalam rentangnilai 50 sampai 69 merupakan retardasi mental ringan, atau termasuk lemah pikiran (feeble-mindedness) atau subnormalitas`mental ringan atau oligofrenia ringan atau moron.

Untuk menetahui ada tidaknya gangguan depresi pada mitra dilakukan pemeriksaan wawancara tersetruktur dengan menggunakan instrumentasi kuesioner depresi dari pedoman penggolongan gangguan jiwa di Indonesia edisi tiga (PPDGJ-III) yang dikeluarkan oleh kementrian kesehatan, dimana instrumentasi tersebut kata-katanya telah disederhanakan, sehingga mudah difahami dan dimengerti oleh mitra, dalam pelaksanaan wawancara terstruktur tersebut dibantu oleh dua mahasiswa kepaniteraan klinik fakultas kedokteran universitas islam sultan agung (FK.Unissula) semarang yang sedang melakukan kegiatan orientasi. Kuesioner tersebut adalah meliputi gejala utama depresi dan gejala tambahan, gejala utama terdiri dari tiga (3) gejala sebagai berikut: 1) apakah mitra pada roman mukanya tampak murung sedih atau tidak, 2) apakah akhir-akhir ini mitra merasakan ada kehilangan minat dan kegembiraan atau tidak, dan 3) apakah akhir-akhir ini mitra mengalami mudah lelah dalam berkativitas sehari-hari atau tidak. Sedangkan gejala tambahan terdiri dari tujuh (7) gejala sebagai berikut: 1) bagaimanakah kondisi konsentrasi dan perhatian mitra, 2) bagaimanakah kondisi perasaan harga diri dan rasa percaya diri mitra berkurang atau tidak, 3) apakah mitra ada perasaan bersalah dan merasa tidak berguna atau tidak, 4) apakah ada atau tidak mitra merasakan adanya rasa pesimis dan merasa masa depan suram, 5) apakah mitra merasakan ada atau tidak adanya gagasan yang merasa dirinya tidak berguna, 6) adakah akhir-akhir ini mitra merasakan ada atau tidaknya gangguan tidur atau susah tidur atau tidak, 7) adakah akhir-akhir ini mitran merasakan nafsu makannya berkurang, terganggu atau tidak. Bila dalam kurun waktu sekurang-kurangnya dalam dua (2) minggu terakhir ini mitra tidak terdapat gejala utama dan juga tidak terdapat gejala tambahan, maka mitra tidak mengalami gangguan depresi, apabila mitra mengalami satu (1) gejala utama dan satu gejala tambahan, maka mitra terdapat symtom depresi belum mengalami gangguan depresi, apabila mitra terdapat dua (2) keluhan gejala utama dan juga terdapat dua (2) keluhanb gejala tambahan maka mitra mengalami gangguan depresi ringan, bila mitra terdapat keluhan gejala utama dua (2) dan terdapat gejala tambahan tiga (3), maka mitra dinyatakan mengalami gangguan depresi sedang, bila mitra mengalami tiga (3) gejala utama ada semuanya dan ditambah empat (4) gejala tambahan, maka mitra mengalami gangguan depresi berat.

Untuk membantu menyelesaikan permasalahan yang dihadapi oleh mitra tersebut diatas, penting akan adanya pemberian solusi bagi mitra dan mitra juga sangat membutuhkan dukungan psikososial, seperti pemberian edukasi untuk meningkatkan pengetahuan mitra secara umum dan kesadaran akan pemahaman terkait kondisis retardasi mental yang dideritanya.

\section{4 || Indonesian Journal of Community Services}


Dengan melihat kondisi dan permasalahan mitra tersebut diatas, selain pemberian solusi tersebut diatas juga perlu diberikan solusi dengan pemberian dukungan psikososial kepada mitra agar mereka dapat termotivasi, dapat memahami dan menyadari akan adanya potensi yang dimiliki, tertap semanagt dalam hidup dan belajar di sekolah, mempunyai cita-cita yang mulia, dapat merasakan kesenangan, bahagia dan dapat hidup secara mandiri. Proses program kemitraan masyarakat pemberian dukugang psikososial kepada mitra dilaksanakan dalam 3 tahap yaitu: tahap persiapan, tahap pelaksanaan, dan tahap pengakhiran/penutup. Pada kenyataannya, dukungan psikososial pada penderita retardasi mental di SLB belum banyak diberikan dan juga belum berjalan secara optimal sebagaimana ketentuan semestinya, sehingga masih banyak anak-nak penderita gangguan retardasi mental yang tidak memiliki keterampilan bersosialisasi dengan baik, tidak mampu belajar dengan baik, dan tidak mampu mandiri apabila mereka kembali ke dalam kehidupan keluarga atau masyarakat, sehingga mereka akan tetap menjadi beban bagi keluarga dan masyarakat

Dalam pemberianberian dukungan psikososial program pengabdian kemitraan masyarakat ini, mitra dikelompokkan dalam masing-masing ruang kelas dari kelas satu (1) sampai dengan kelas enam (6), karena di SLB Widya Bhakti tidak ada ruangan besar yang bisa menampung banyak siswa, sehingga pelaksanaan dukungan psikososial dilakukan secara bergantian setiap masing-masing kelas dilakukan pendekatan psikososial meliputi beberapa kegiatan dan tahapan sebagai berikut: Pada tahap pertama adalah melakukan permohonanan ijin kepada kepala sekolah, setelah mendapatkan ijin dari kepala sekolah SLB, selanjutnya tim pengusul pengabdian dan pihak mitra mengadakan rapat koordinasi dan kesepakantan bersama dengan pihak pimpinan SLB dengan tim pengusul pengabdian, rapat koordinasi dapat dilihat dalam gambar 1. Selanjutnya pihak pimpinan SLB akan menyampaikan hasil rapat koordinasi dimana informasi diteeruskan kepada masing-masing guru kelas dari guru kelas 1 sampai dengan guru kelas 6 bahwa akan diadakan kegiatan program kemitraan masyarakat dengan pendekatan psikososial bagi anak-anak retardasi mental. 


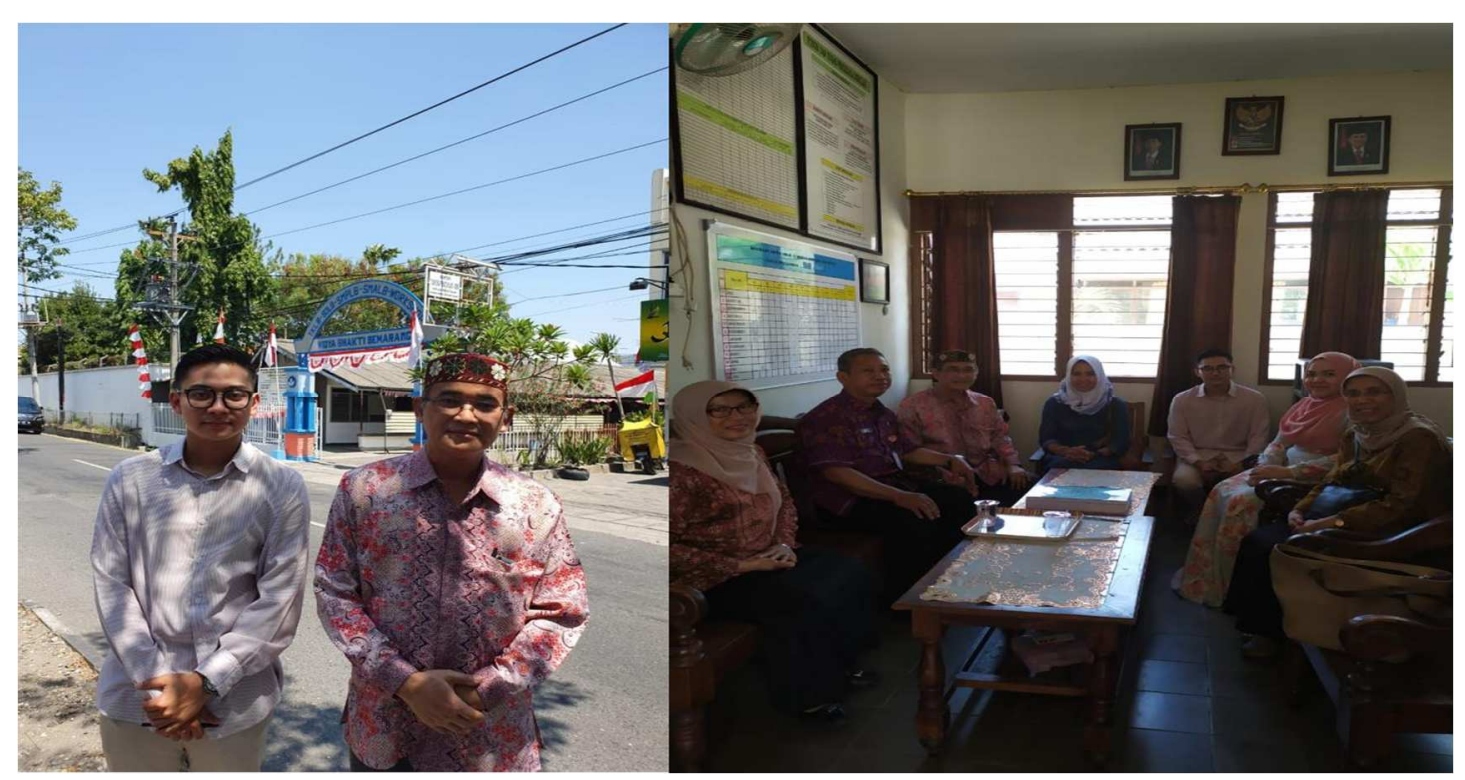

Gambar 1.: Foto Pintu Gerbang SLB Widya Bhakti dan Foto Rapat koordinasi

Pada tahap kedua, setelah masing-masing guru kelas mendapatkan pemberitahuan dan persetujuan bersama, selanjutnya dari tim pelaksana pengabdian kemitraan masyarakat fakultas kedokteran Unissula Semarang memasuki masing-masing kelas dengan terlebih dahulu 1) menyampaikan maksud dan tujuan diadakannya kegiatan ini, 2) melakuakn perkenalan dan sambung rasa dengan masing-masing guru kelas dan siswa-siswi, 3) kepada masing-masing siswa-siswi diberikan bulpen warna warni dan buku berwana (coloring book) seri unggas yang didalamnya terdapat gambar berwarna dari beberapa unggas seperti: kalkun (turkey), merak (peacock), burung tanduk (hornbill), elang (eagle), kakaktua (cockatoo), ayam (chiken), pelikan (pelican), bebek (duck), burung onta (ostrich), angsa (swan), burung dara (pigeon), dan burung nazar (vulture), 4) kemudian kepada mitra siswa-siswi diminta membuka dan mengamati masing-masing gambar unggas dalam buku berwarna tersebut untuk dikenalkan dan diberikan penjelasan terhadap macam-macam unggas tersebut dengan memperlihatkan gambar-gambar berwana, perihal ciri masing-masing unggas, cara berjalan atau terbang atau berenang, cara beranak/bereproduksi, dan mana unggas yang bisa dimakan atau tidak untuk lauk, untuk perbaikan gizi, siapa saja anak-anak yang pernah merasakan dagingnya, siapa yang belum, dan lain-lain, 5) selanjutnya ditanyakan kepada masing-masing siswa-siswi siapakah yang pernah melihat unggas tersebut, dimana saat melihat unggas tersebut, ada yang memiliki unggas tersebut apa tidak, jenis unggas apa yang dimiliki, 6) selanjutnya mitra siswa-siswi diajak bernyayi bersama dengan nyanyian dipilihkan sesuai unggas yang ada dalam buku seperti nyanyian: bebek adus kali, potong bebek, anak ayam, burung kakak tua, dan lain-lain, 7) selanjutnya mitra anak-anak diminta tepuk tangan dan melakukan permainan sederhana, foto kegiatan dapat dilihat pada gambar 2. Sebelum tahap kedua berakhir dalam proses pelaksanaan program kemitraan dukungan psikososial ini terkadang juga dilakukan pengambilan foto-foto kegiatan untuk dokumen bukti kegiatan PKM dari masing-masing kelas dari kelas 1 hingga sampai dengan kelas 6. 


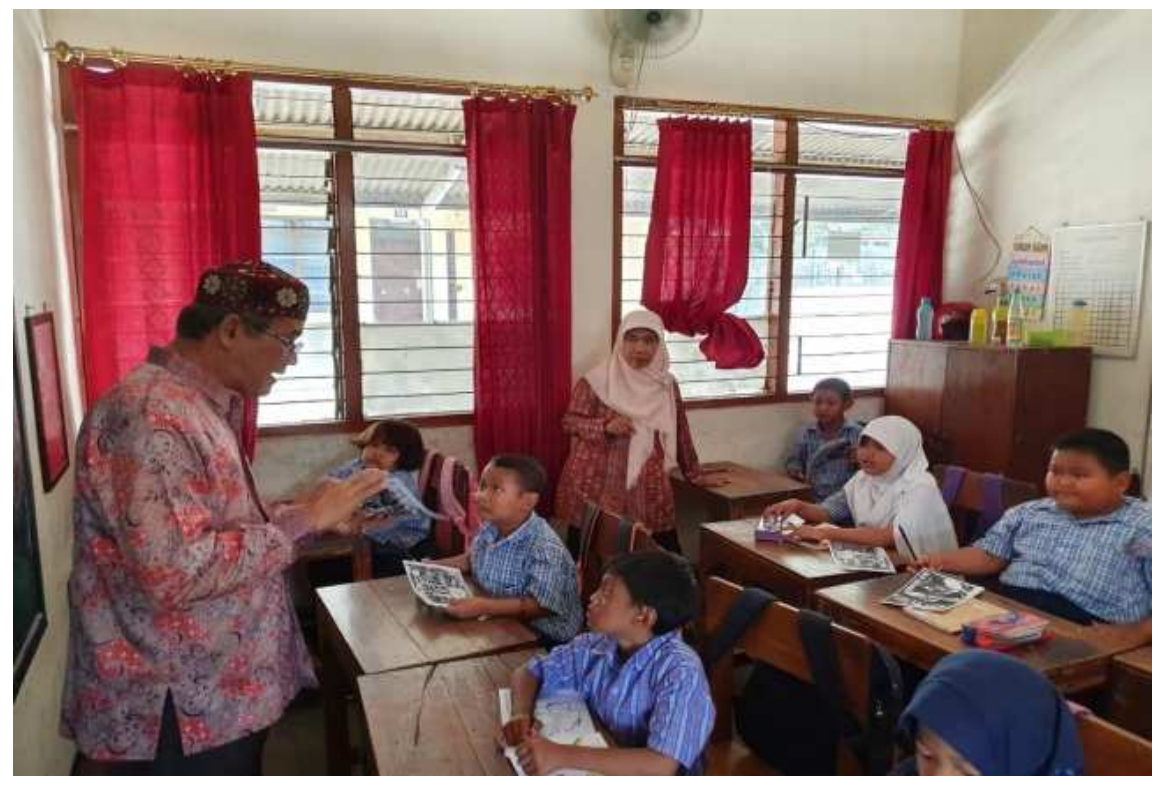

Gambar 2: Foto Kegiatan PKM Dukungan Psikososial.

Pada tahap ketiga, karena kegiatan dilaksanakan pada bulan agustus 2019 dan bertepatan dengan hari kemerdekaan negara kesatuan republik Indonesia (NKRI) yang ke 74 maka kepada mitra siswa-siswi SLB selanjutnya diberikan penjelasan tekait kisah-kisah perjuangan para pahlawan kemerdekaan, pahlawan nasional dengan memperlihatkan beberapa gambar para pahlawan tersebut, juga diberikan buku "kumpulan lagu wajib nasional dan daerah", yang didalamnya berisi lagu-lagu wajib nasional dan daerah, mitra selanjutnya diajak bersama-sama menyanyikan nyanyian-nyanyian lagu nasional dan daerah, selanjutnya kepada mitra juga diperlihatkan buku kumpulan lagu wajib nasional dan daerah dengan memperkenalkan kepada siswa-siswi beberapa lagu-lagu yang pendek, 1) mitra siswa-siswi di minta memilih beberapa lagu-lagu yang pernah tau atau dipilih beberapa lagu secara bersama-sama seperti lagu: indonesia raya, bendera merah putih, garuda pancasila, maju tak gentar, hari kemerdekaan, indonesia tetap merdeka,satu nusa satu bangsa, padamu negeri, syukur, dan lain-lain, 2) kemudian kepada mitra siswa-siswi diminta memilih beberapa diantara lagu-lagu tersebut antara 2-3 lagu, 3) selanjutnya mitra siswa-siswi diajak nyanyi bersama-sama, dan 4) setelah selesai nyayi bersama-sama, kemudian mitra diajak tepuk tangan bersama. d) setelah itu selanjunya disampaikan ceramah dan pemberian motivasi kepada siswa-siswi agar tetap semangat dalam belajar dengan baik dan tekun, agar dikemuan hari bisa menjadi anak-anak yang sholih-sholihah berguna kepada kedua orang tua, bergunaa kepada nusa bangsa dan agama, 3) penutup, sebelum acara PKM ini selesai terlebih dahulu dilakukan doa bersama, selanjutnta dilakukan peneutupan, dengan tim pemberi materi mohon diri untuk pamitan, sambil bersalam-salaman, memohon maaf dan mengucapkan terimma kasih.

\section{HASIL DAN PEMBAHASAN}

Mitra pengabdian masyarakat Program Kemitraan Masyarakat (PKM) dukungan psikosososial adalah siswa-siswi anak retardasi mental yang belajar di sekolah luar biasa (SLB) Widya Bhakti jalan Supriyadi nomor 12 Semarang, anggota ada sebanyak 45 siswa/siswi, mitra yang tidak hadir dalam kegiatan PKM ini ada 3 siswa, yaitu anak kelas 2 ada 1 siswa, dan anak kelas 3 ada 2 siswi, jadi jumlah mitra yang ikut dalam pengabdian kemitraan masyarakat (PKM) ini 
ada sebanyak 42 siswa. Sebelum dilakukan intervensi psikososial siswa siswi SLB Widya Bhakti didata terlebih dahulu mengenai data demografi siswa-siswi berdasarkan jenis kelamin, umur, agama, alamat tempat tinggal, kelas, dan pekerjaan orang tua mitra, kemudian dilakukan intervensi psikososial, berupa remidiasi kognitif, permainan sederhana, cerita beberapa unggas dalam coloring book, nyanyian-nyanyian unggas dan beberapa nyanyian-nyanyian nasional dan daerah, nyanyian lagu-lagu perjuangan karena kegiatan ini dilaksanakan pada bulan agustus, setelah dilakukan intervensi psikososial mitra diminta mengisi kuesioner respon dan tanggapan mitra terhadap dekungan psikososial tersebut dengan dipandu oleh dua mahasiswa kepaniteraan klinik bagian ilmu kedokteran jiwa (psikistri) fakultas kedokteran Unissula Semarang. Total mitra yang mengikuti kegiatan program kemitraan masyarakat dukungan psikososial ini ada sebanyak 42 anak.

Data demografi mitra dapat dilihat pada tabel 1, setelah dilakukan analisis deskriptif berdasarkan beberapa variabel yang ada dalam kegiatan program kemitraan masyarakat, didapatkan data berdasarkan jenis kelamin mitra terbanyak adalah laki-laki ada 27 siswa $(64,3$ $\%)$ dan berdasarkan jenis kelamin perempuan ada 15 siswi $(35,7 \%)$ dan jenis kelamin ganda tidak ada $(0 \%)$, berdasarkan umur mitra didapatka umur rentang antara 8-10 tahun ada sebanyak 13 siswa/siswi (13,9 \%) umur rentang antara 11-13 tahun ada sebanyak 23 siswa/siswi $(54,8 \%)$ dan umur rentang antara 14-16 tahun ada sebanyak 6 siswa/siswi (14,4 \%), berdasarkan agama yang dianut mitra didapatkan mitra yang beragama Islam ada sebanyak 39 siswa/siswi $(92,8 \%)$ mitra yang beragama Kristen ada sebanyak 2 siswa $(4,8 \%)$ dan mitra yang beragama katolik ada sebanyak 1 siswa $(2,4 \%)$, kemudian data berdasarkan alamat mitra yang menyatakan beralamat di kota Semarang ada sebanyak 36 siswa/siswi (85,6 \%), mitra yang beralamat di kabupaten Demak ada sebanyak 6 siswa/siswi $(14,4 \%)$, dan mitra yang beralamat di kota lain tidak ada (0\%), berdasarkan kelas mitra yang menyatakan duduk di kelas 1-2 ada sebanyak 15 siswa/siswi (35,7 \%) mitra yang menyatakan duduk di kelas 3-4 ada sebanyak 13 siswa/siswi $(30,9 \%)$ dan mitra yang menyatakan duduk di kelas 4-6 ada sebanyak 14 siswa/siswi $(33,4 \%)$, berdasarkan pekerjaan orang tua, mitra yang menyatakan pekerjaan orang tua adalah TNI/Asn ada sebanyak 3 siswa/siswi $(7,2 \%)$ mitra yang menyatakan pekerjaan orang tua swasta ada sebanyak 31 siswa/siswi $(73,8 \%)$ dan mitra yang menyatakan pekerjaan orang tua wiraswasta ada 8 siswa/siswi (19\%). 
Indonesian Journal of Community Services

Volume 2, No. 2, November 2020

http://jurnal.unissula.ac.id/index.php/ijocs

DOI: http://dx.doi.org/10.30659/ijocs.2.2.151-161

Tabel 1. Data demografi mitra

\begin{tabular}{|c|c|c|c|}
\hline Data Demografi & Jumlah & Total Peserta & Prosentase \\
\hline $\begin{aligned} \text { Jenis } & \text { Kelamin } \\
- & \text { Laki - laki } \\
- & \text { Perempuan } \\
- & \text { Ganda }\end{aligned}$ & $\begin{array}{l}27 \\
15 \\
0\end{array}$ & 42 & $\begin{array}{l}64,3 \% \\
35,7 \% \\
0 \%\end{array}$ \\
\hline $\begin{array}{cl}\text { Umur } & \\
- & 8-10 \text { tahun } \\
- & 11-13 \text { tahun } \\
- & 14-16 \text { tahun } \\
\end{array}$ & $\begin{array}{l}13 \\
23 \\
6 \\
\end{array}$ & 42 & $\begin{array}{l}30,9 \% \\
54,8 \% \\
14,4 \%\end{array}$ \\
\hline $\begin{array}{cl}\text { Agama } & \\
- & \text { Islam } \\
- & \text { Kristen } \\
- & \text { Katolik } \\
\end{array}$ & $\begin{array}{l}39 \\
2 \\
1 \\
\end{array}$ & 42 & $\begin{array}{l}92,8 \% \\
4,8 \% \\
2,4 \% \\
\end{array}$ \\
\hline 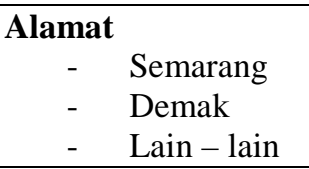 & $\begin{array}{l}36 \\
6 \\
0\end{array}$ & 42 & $\begin{array}{l}85,6 \% \\
14,4 \% \\
0 \%\end{array}$ \\
\hline $\begin{array}{rr}\text { Kelas } & \\
- & 1-2 \\
- & 3-4 \\
- & 4-6 \\
\end{array}$ & $\begin{array}{l}15 \\
13 \\
14 \\
\end{array}$ & 42 & $\begin{array}{l}35,7 \% \\
30,9 \% \\
33,4 \% \\
\end{array}$ \\
\hline $\begin{array}{cl}\text { Pekerjaan orang tua } \\
- & \text { TNI / ASN } \\
- & \text { Swasta } \\
- & \text { Wiraswasta }\end{array}$ & $\begin{array}{l}3 \\
31 \\
8\end{array}$ & 42 & $\begin{array}{l}7,2 \% \\
73,8 \% \\
19 \%\end{array}$ \\
\hline
\end{tabular}

Setelah dilakukan kegiatan pengabdian program kemitraan masyarakat (PKM) dengan pendekatan intervensi psikososial terdapat mitra anak retardasi mental yang sedang sekolah di SLB Widya Bhakti jalan Supriyadi nomor 12 Semarang pada bulan Agustus tahun 2019. Hasil dari kegiatan tersebut dapat dilihat dalam tabel 2 di mana dalam tabel tersebut mitra menayatan bahwa kegiatan PKM ini menyenangkan ada sebanyak 42 anak (100 \%), mitra yang menyatakan kurang menyenangkan tidak ada $(0 \%)$, dan mitra yang menyatakan tidak menyenangkan juga tidak ada $(0 \%)$, dari segi manfaat kegiatan PKM mitra yang menyatakan bermanfaat ada sebanyak 42 anak (100\%), mitra yang menyatakan kurang bermanfaat tidak ada ( $0 \%$ ) dan mitra yang menyatakan tidak bermanfaat juga tidak ada $(0 \%)$, dari segi diperlukan tidaknya kegiatan PKM ini, mitra yang menyatakan kegian PKM ini diperlukan ada sebanyak 37 anak $(88,1 \%)$ yang menyatakan kurang diperlukan ada 5 anak $(11,9 \%)$ dan yang menyatakan tidak diperlukan tidak ada $(0 \%)$, dari segi baik tidaknya kegiatan PKM ini, mitra yang menyatakan bahwa kegiatan PKM ini baik sebanyak 42 anak (100 \%) mitra yang menyakan kurang baik tidak ada ( $0 \%)$ dan mitra yang menyatakan tidak baik juga tidak ada $(0$ $\%$ ), dari fariabel disukainya kegiatan PKM ini atau tidak, mitra yang menyatakan menyukai kegiatan kegiatan PKM ada sebanyak 38 anak (90,5 \%), mitra yang menyatakan kurang menyukai kegiatan PKM ada sebanyak 4 anak $(9,5$ 5) dan mitra yang menyatakan tidak menyukai kegiatan PKM ini tidak ada (0\%). 
Tabel 2. Respons dan tanggapan mitra terhadap kegiatan PKM (Post Test).

\begin{tabular}{|c|c|c|c|c|c|}
\hline No & Kuisioner & Respon & Jumlah & $\begin{array}{l}\text { Total } \\
\text { Peserta }\end{array}$ & Prosentase \\
\hline \multirow[t]{3}{*}{1.} & kegiatan & Menyenangkan & 42 & \multirow{3}{*}{42} & $100 \%$ \\
\hline & menyenangkan? & Kurang & 0 & & $0 \%$ \\
\hline & & Tidak & 0 & & $0 \%$ \\
\hline \multirow[t]{3}{*}{2.} & kegiatan & Bermanfaat & 42 & \multirow{3}{*}{42} & $100 \%$ \\
\hline & bermanfaat? & Kurang & 0 & & $0 \%$ \\
\hline & & Tidak & 0 & & $0 \%$ \\
\hline \multirow[t]{3}{*}{3.} & kegiatan & Diperlukan & 37 & \multirow{3}{*}{42} & $88.1 \%$ \\
\hline & perlukan? & Kurang & 5 & & $11,9 \%$ \\
\hline & & Tidak & 0 & & $0 \%$ \\
\hline \multirow[t]{3}{*}{4.} & Apakah kegiatan ini baik? & Baik & 42 & \multirow{3}{*}{42} & $100 \%$ \\
\hline & & Kurang & 0 & & $0 \%$ \\
\hline & & Tidak & 0 & & $0 \%$ \\
\hline \multirow[t]{3}{*}{5.} & Apakah menyukai kegiatan? & Suka & 38 & \multirow{3}{*}{42} & $90,5 \%$ \\
\hline & & Kurang & 4 & & $9,5 \%$ \\
\hline & & Tidak & 0 & & $0 \%$ \\
\hline
\end{tabular}

Data-data tersebut diatas menggambarkan bahwa kegiatan program kemitraan masyarakat (PKM) berupa pemberian dukungan psikososial kepada anak penderita retardasi mental di sekolah luar biasa Widya Bhakti jalan Supriyadi nomor 12 Semarang secara keseluruhan dapat terlaksana dengan baik dan lancar serta mendapatkan tanggapan yang positip dan antusias dari mitra, dimana mitra kebanyakan menyatakan bahwa kegiatan ini menyenangkan, bermanfaat, baik, dan disukai.

\section{KESIMPULAN}

Mitra dalam kegiatan program kemitraan masyarakat (PKM) dukungan psikososial anak rewtardasi mental di SLB widya Bhakti jalan Supriyadi nomor 12 Semarang sebanyak 42 anak, data demografi mitra berdasarkan jenis kelamin terbanyak adalah laki-laki ada 27 anak $(64,3$ $\%)$, umur terbanyak adalah rentang antara 11-13 tahun sebanyak 23 anak (54,8\%), agama mitra terbanyak adalah Islam ada 39 anak $(92,8 \%)$, alamat mitra terbanyak ada di kota Semarang sebanyak 36 anak (85,6 \%), kelas mitra terbanyak adalah kelas 1-2 ada 15 anak (35,7 $\%)$, dan pekerjaan orang tua mitra terbanyak adalah swasta ada 31 anak $(73,8 \%)$. Tanggapan mitra setelah diadakan kegiatan PKM ini adalah baik dan positip, mitra banyak yang menayatan bahwa kegaiatn PKM dukungan psikososial ini adalah menyenangkan, bermanfaat bagi mitra, diperlukaan oleh mitra, baik bagi mitra, dan disukai oleh mitra yaitu anak-anak retardasi mental yang sedang sekolah di SLB Widya Bhakti Semarang.

\section{UCAPAN TERIMA KASIH}

Ucapan terima kasih disampaikan kepada:Lembaga Penelitian dan Pengabdian kepada Masyarakat (LPPM) Universitas Islam Sultan Agung (Unissula) Semarang yang telah membiayai kegiatan Program Kemitraan Masyarakat ini, juga kepada Sekolah Luar Biasa (SLB) Widya Bhakti jalan Supriyadi nomor 12 Semarang sebagai mitra kegiatan Program Kemitraan 
Masyarakat ini serta Indonesian Journal of Community Services (IJoCS), jurnal online pengabdian masyarakat Universitas Islam Sultan Agung (Unissula) Semarang yang telah berkenan menerbitkan artikel kegiatan Program Kemitraan Masyarakat (PKM) dukungan psikososial pada mitra anak-anak retardasi mental di SLB Widya Bhakti Semarang ini.

\section{DAFTAR PUSTAKA}

Cahyadi, M. S. (2015). Melatih mental sukses tahan banting. Yogyakarta: Indoliterasi.

Canfield, J., Hansesn, M. V., Newmark, A. (2015). Kekuatan berpikir positif. Jakarta: Gramedia Pustaka Utama.

Fancy, I. (2017). Coloring book seri unggas. Semarang: CV. Aneka Ilmu.

Fancy, I. (2017). Kumpulan lagu wajib nasional dan daerah. Semarang: CV. Aneka Ilmu.

Huda, A. N., dkk. (2019). Hubungan retardasi mental dengan depresi pada anak siswa SLB Widya Bhakti Semarang tahun 2019. Penelitian Internal Unissula, Semarang.

Huda, A. N., dkk. (2017). Hubungan dukungan sosial dengan penyalahgunaan narkoba di Panti Rehabilitasi Narkoba Rumah Damai Gunung Pati. Penelitian internal Unissula, Semarang.

Humries, W. E. (2010). Retardasi mental dalam buku ajar psikiatri. Jakarta: Badan Penerbit FK UI. hal: 411-419.

Ilmi, U. N. (2011). Hubungan tingkat pendidikaan dan dukungan sosial dengan tingkat depresi pada penderita kanker payudara. Unissula Press, Semarang, hal: 19.

Kaplan, H. I. \& Sadock, B. J. (2012). Retardasi mental dalam buku ajar psikiatri. EGC, Jakarta, hal: 561-571

Salim, A. (2011). Teori dan paradigma penelitian sosial. Yogyakarta: Tiara Wicana.

Soetjiningsih, IGN G. R. (2013). Tumbuh kembang anak. Jakarta: EGC. hal: 511-526.

Suindriani, C. (2012). Hubungan dukungan sosial dengan tingkat depresi pada lansia di Unit Rehabilitasi Sosial Pucanggading Semarang. Unissula Press, Semarang, hal: 20-28.

Szar, D. H. (2015). Disabilitaas intelektual retardasi mental dalam Buku Seri Crash Course. Wisland House, Singapore, hal: 361-368. 